\title{
Upaya Meningkatkan Keterampilan Sosial dan Kerjasama Anak dalam Bermain Angin Puyuh di TK Al-Akbar Kota Jambi Tahun 2017/2018
}

\author{
Gustika Ayu'
}

\begin{abstract}
Abstrak: Tujuan penelitian adalah untuk meningkatkan keterampilan sosial dan kerjasama anak dalam bermain angin puyuh dan faktor pendukung dan kendala dari permainan angin puyuh dalam meningkatkan keterampilan sosial dan kerjasama anak di TK Al-Akbar Kota Jambi. Penelitian Tindakan Kelas dilakukan di TK Al-Akbar Kota Jambi. Metode yang digunakan dalam penelitian adalah metode Penelitian Tindakan Kelas. Penelitian dilaksanakan dalam tiga siklus, tiap siklus terdiri atas tahapan perencanaan, tindakan, observasi, dan refleksi. Pengambilan data kuantitatif dan kualititatif. Indikator keberhasilan adalah sebagai berikut: meningkatnya keterampilan sosial dan kerjasama anak lebih dari $80 \%$ dan kenerja guru minimal Baik yaitu dengan persentase 3,00. Dari analisis data penelitian siklus I diperoleh hasil kemampuan keterampilan sosial dan kerjasama anak dalam bermain angin puyuh adalah $45 \%$ dengan kategori sangat kurang, kemudian dilanjutkan perbaikan ke siklus II dan hasil penelitian meningkat sebesar $70 \%$ dengan kategori cukup. Untuk lebih memaksimalkan keterampilan sosial dan kerjasama anak melalui bermain angin puyuh, peneliti melanjutkan perbaikan ke siklus III dengan peningkatan sangat baik menjadi $90 \%$. Berdasarkan dari hasil penelitian peneliti menyimpulkan bahwa dengan bermain angin puyuh di TK Al-Akbar Kota Jambi dapat meningkatkan keterampilan sosial dan kerjasama anak dan juga meningkatkan kinerja guru. Berdasarkan dari hasil penelitian dapat disarankan untuk menggunakan permainan angin puyuh dalam memberikan pembelajaran terutama untuk meningkatkan keterampilan sosial dan kerjasama pada anak usia dini.
\end{abstract}

Kata Kunci: keterampilan sosial, kerjasama dan bermain angin puyuh.

Abstract: Social skills and collaboration of children in playing games and supporting factors and constraints of the whirlwind game in improving social skills and collaboration of children in Al-Akbar Kindergarten, Jambi City. Classroom Action Research was conducted at Al-Akbar Kindergarten, Jambi City. The method used in research is the Classroom Action Research method. Research was conducted in three cycles, each cycle consisted of stages of planning, action, observation, and reflection. Quantitative and qualitative data collection. Indicators of success are as follows: increasing social skills and cooperation more than $80 \%$ and minimum teacher performance Good percentage of 3.00. From the data analysis of first cycle research, the results of the ability of social skills and the collaboration of children in playing areas were $45 \%$ with very less categories, then improvements to the results of the study increased by $70 \%$ with sufficient categories. To further maximize the social skills and collaboration of children through playing, the research continues to improve the third cycle with a very good increase to $90 \%$. Based on the results of the study, the researchers concluded that playing the game at Al-Akbar Kindergarten in Jambi City could improve social skills and child cooperation and improve teacher performance. Based on the results of the study, it can be suggested to use a whirlwind game in providing learning especially to improve social skills and cooperation in early childhood.

Keywords: social skills, collaboration and playing a whirlwind.

\section{PENDAHULUAN}

Taman Kanak-Kanak (TK) adalah salah satu bentuk pendidikan dini bagi anak usia empat tahun sampai memasuki pendidikan dasar. Tujuan program kegiatan belajar di TK adalah untuk membantu perkembangan sikap, pengetahuan, keterampilan dan daya cipta yang diperlukan oleh anak dalam menyesuaikan diri dengan lingkungan untuk pertumbuhan serta perkembangan selanjutnya.

Kerjasama menurut Saputra (2005:39) adalah gejala saling mendekati untuk mengurus kepentingan bersama dan tujuan yang sama. Perkembangan keterampilan sosial anak dan kerjasama sangat dipengaruhi oleh kondisi anak dan lingkungan sosialnya, baik orang tua, teman sebaya, dan masyarakat sekitar.

Bermain memiliki beberapa manfaat yang baik untuk anak, manfaat tersebut antara lain bisa menjadi sarana hiburan yang menyediakan interaksi sosial, membangun semangat kerjasama atau teamwork ketika dimainkan, bermain bisa meningkatkan rasa percaya diri dan harga diri anak saat mereka mampu menguasai permainan. Bermain juga dapat mengembangkan kemampuan membaca, matematika, dan memecahkan

\footnotetext{
${ }^{1}$ Guru TK Al-Akbar Kota Jambi
} 
masalah atau tugas. Bermain membuat anak-anak merasa nyaman dan familiar dengan teknologi, terutama bagi anak perempuan yang tidak menggunakan teknologi sesering anak laki-laki. Bermain dapat melatih koordinasi antara mata dan tangan, serta skill motorik, dan dengan bermain dapat mengakrabkan hubungan anak dengan orangtua sehingga terjalin komunikasi satu sama lain.

Untuk itu bermain tidak hanya memberikan dampak positif tetapi juga memulihkan kesehatan untuk beberapa kasus penyembuhan dan bagi orang dewasa bermain dapat mengurangi efek kepikunan yang dapat memperlambat berfikir. Bermain dengan permainan yang tepat akan memberikan banyakmanfaat bagi diri sendiri dan oranglain.

Permainan angin puyuh adalah salah satu Junas permainan terpimpin yang membutuhkan kerjasama anak dalam kelompok untuk meningkatkan keterampilan sosial. Di dalam kegiatan bermain terpimpin anak tidak bebas, melainkan terikat pada peraturan permainan atau kegiatan tertentu (B.E.F Montolalu. 2009:7.29). Kekuatan atau kelebihan dari permainan angin puyuh ini adalah bahwa permainan ini berbentuk permainan lomba yang menarik untuk dimainkananak secara berkelompok atau membentuk tim. Anak melakukan permainan dengan anggota timnya. Permainan ini memiliki kolaborasi sehingga media yang digunakan selalu berbeda. Permainan angin puyuh yang sebenarnya menggunakan media bola pingpong, tetapi untuk menambah ketertarikan anak dengan permainan angin puyuh, peneliti membuat kolaborasinya.

Terdapat beberapa kolaborasi Permainan Angin Puyuh, antara lain: 1. Permainan Angin Puyuh dengan Kantong Plastik. 2. Permainan Angin Puyuh dengan Bulu Ayam. 3. Permainan Angin Puyuh dengan lilin. 4. Permainan Angin Puyuh dengan Sedotan.

Anak memiliki perkembangan keterampilan sosial dan kerjasama dengan baik, apabila orangtua memberikan pola asuh yang baik, namun kebanyakan para orang tua sering beranggapan bahwa keterampilan sosial kerjasama anaknya tidaklah begitu penting untuk diperhatikan dalam kehidupannya. Salah satu penyebab masih kurangnya keterampilan sosial dan kerjasama anak adalah metode pengajaran kurang memiliki variasi dalam bermain, serta pembagian tugas kepada anak seringkali bersifat individual atau tidak berkelompok. Proses pembelajaran tanpa adanya kegiatan bermain akan mengakibatkan anak cepat bosan dan jenuh di kelas sehingga diperlukan upaya yang baru untuk meningkatkan keterampilan sosial dan kerjasama anak agar lebih optimal yaitu dengan bermain Angin Puyuh.

Bermain Angin Puyuh adalah salah satu Junas kegiatan bermain yang diajarkan kepada anak untuk mengembangkan keterampilan sosial dan kerjasama, karena permainan ini merupakan Junas permainan terpimpin yang membutuhkan kerjasama dalam kelompok. Sehingga anak harus berinteraksi dengan teman untuk menyelesaikan permainannya. Jika anak saling berinteraksi dengan teman, dan bekerjasama maka akan terlihat keterampilan sosial anak. Untuk meningkatkan keterampilan sosial dan kerjasama pada anak Taman Kanak-kanak melalui permainan ini, pelaksanaannya di sekolah dimasukkan kegiatan pembelajaran. Adapun dalam pelaksanaannya di sekolah tidak menutup kemungkinan akan menemui hambatan. Kendalakendala yang mungkin muncul pada saat anak-anak melakukan permainan ini misalnya pemahaman orang tua dan guru yang kurang mendukung terhadap aktivitas bermain yang dilakukan oleh anak.

Salah satu ciri khas keterampilan sosial yang berkembang adalah kerjasama, belajar kerjasama yang mengembangkan kognitif maupun sosial. Kerjasama adalah gejala saling mendekati untuk mengurus kepentingan bersama dan tujuan bersama. Kerjasama dan pertentangan merupakan dua sifat yang dapat dijumpai dalam seluruh proses sosial atau masyarakat, diantara seseorang dengan oranglain, kelompok dengan kelompok, dan kelompok dengan seseorang. Pada umumnya kerjasama menganjurkan persahabatan, akan tetapi kerjasama dapat dilakukan diantara dua pihak yang tidak bersahabat, atau bahkan bertentangan. Kerjasama diantara dua pihak yang bertentangan dinamakan kerjasama berlawanan (antagonic cooperation), merupakan suatu kombinasi yang amat produktif dalam masyarakat modern. (Carol seefeldt \& Barbara, $2008: 177)$

Menurut Yudha (2005: 54) tujuan kerjasama untuk anak usia dini yaitu Untuk lebih menyiapkan anak didik dengan berbagai ketrampilan baru agar dapat ikut, berpartisipasi dalam dunia yang selalu berubah dan terus berkembang, membentuk kepribadian anak didik agar dapat mengembangkan kemampuan, berkomunikasi dan bekerjasama dengan orang lain . Kemampuan kerjasama bertujuan mengembangkan kreativitas anak dalam berkelompok atau bermain bersama teman-temannya karena jika anak tidak memiliki kemampuan kerjasama anak belum dapat membedakan antara kondisi dirinya dengan kondisi orang lain atau anak lain di luar dirinya. Dari uraian di atas peneliti dapat menyimpulkan bahwa tujuan kemampuan 
kerjasama yaitu untuk mengajak anak agar dapat saling tolong menolong, untuk menciptakan mental anak didik yang penuh rasa percaya diri agar dapat dengan mudah beradaptasi dengan lingkungan baru, serta dapat meningkatkan sosialisasi anak terhadap lingkungan.

Bermain dapat sambil belajar, namun dalam bermain terdapat karakteristik yang dapat membedakan bermain dengan belajar. Karakteristikbermain pada anak menurut Hariwijaya dan Bertiani (2009:104) yaitu bermain dilakukan secara sukarela tanpa paksaan, bermain merupakan kegiatan yang menyenangkan sehingga dapat dinikmati oleh anak-anak, tanpa adanya paksaan kegiatan bermain itu sendiri sudah menyenangkan. Tujuan bermain adalah aktivitas bermain itu sendiri, menuntut adanya partisipasi aktif dalam kegiatan bermain dan anak dapat secara bebas mengungkapkan ekspresinya dengan bermain.

\section{METODE PENELITIAN}

Metode Penelitian yang dilakukan dalam penelitian ini adalah menggunakan rancangan Penelitian Tindakan Kelas (PTK) atau classroom action research. Pelaksanaan penelitian ini mengikuti tahap-tahap penelitian tindakan kelas yang pelaksanaan tindakannya terdiri atas beberapa siklus. Setiap siklus terdiri atas pengamatan, pendahuluan atau perencanaan, dan pelaksanaan tindakan. Perencanaan tindakan, pemberian tindakan, observasi, dan refleksi. Tahap-tahap penelitian dalam masing-masing tindakan terdiri secara berulangyang akhirnya menghasilkan beberapa tindakan dalam penelitian kelas. Tahap-tahap tersebut membentuk spiral. Penelitian ini dilaksanakan pada anak-anak kelompok B di TK Al-Akbar Kecamatan Jambi Selatan. Penelitian ini menggunakan satu variabel bebas dan satu variabel terikat, dua variabel tersebut adalah sebagai berikut ; variabel terikat yaitu keterampilan sosial melalui kerjasama pada anak sedangkan variabel bebas yaitu permainan angin puyuh. Populasi penelitian ini adalah anak kelompok B di TK Al-Akbar Kecamatan Jambi Selatan. Adapun jumlah anak yang dimaksud adalah 20 anak, terdiri dari 14 anak laku-laki dan 6 anak perempuan. Sampel diambil dari anak kelompok B.

Sumber data dalam penelitian adalah menggunkan bukti-bukti dokumentasi, gambar, pengamatan dan instrumen. Dalam penelitian ini menggunakan dua teknik pengumpulan data, yaitu observai dan dokumentasi. Bentuk lembar observasi (pengamatan) dimaksud adalah berbentuk daftar dengan daftar checklist pada kategori penilaian. Kategori penilaian ini merupakan petunjuk mengenai gambaran situasi objek yang diamati. Langkah-langkah menggunakan observasi yaitu, pengamat hanya melakukan pengamatan kemudian melihat daftar atau lembar observasi, aspek apa yang muncul dalam pengamatan tersebut kemudian dimasukkan ke tanda checklist pada lembar observasi.

Teknik dokumentasi yaitu mencari data mengenai hal-hal atau variabel yang berupa catatan, transkrip, buku, surat kabar, majalah, prastasi, notulen rapat, agenda, dan sebagainya. Dokumen yang digunakan dalam penelitian ini berupa lembar observasi anak, daftar dan, daftar foto-foto kegiatan anak menggunakan metode ini untuk mendokumentasikan lembar kerja anak dan foto anak yang diambil pada waktu anak dalam kegiatan permainan angin puyuh.

Data yang diperoleh melalui lembar observasi setiap pertemuan dalam setiap siklus dikumpulkan lalu dipresentase berapa siswa yang berhasil ini untuk mengetahui penguasaan anak secara umum. Selanjutnya untuk mendapatkan data anak secara pribadi, peneliti membuat catatan khusus pencapaian anak per siklus.

\section{HASIL DAN PEMBAHASAN Siklus I}

Tabel 1.

Persentase (\%) nilai siklus I

\begin{tabular}{|c|c|c|c|c|c|}
\hline \multirow{2}{*}{ No } & \multirow{2}{*}{ Aspek-Aspek yang diobservasi } & \multicolumn{4}{|c|}{ Jumlah Anak } \\
\hline & & BB & MB & BSH & BSB \\
\hline \multirow[t]{2}{*}{1.} & Anak menyapa teman-temannya untuk Bermain & 11 & 2 & 3 & 4 \\
\hline & & $55 \%$ & $10 \%$ & $15 \%$ & $20 \%$ \\
\hline \multirow[t]{2}{*}{2.} & Anak mengajak banyak teman untuk bermain dalam suatu kelompok & 10 & 2 & 2 & 6 \\
\hline & & $50 \%$ & $10 \%$ & $10 \%$ & $30 \%$ \\
\hline \multirow[t]{2}{*}{3.} & Anak aktif dan mempunyai ide mengadakan permainan & 11 & 2 & 3 & 4 \\
\hline & & $55 \%$ & $10 \%$ & $15 \%$ & $20 \%$ \\
\hline \multirow[t]{2}{*}{4.} & Anak selalu aktif bergabung dalam Bermain & 12 & 3 & 2 & 3 \\
\hline & & $60 \%$ & $15 \%$ & $10 \%$ & $15 \%$ \\
\hline
\end{tabular}


5. Anak terlibat aktif dalam permainan

6. Anak mau bermain sesuai peran di angin puyuh (meniup)

7. Anak tidak memaksakan kehendak kepada teman untuk bermain

8. Anak saling berinteraksi dan berkomunikasi dengan teman

9. Anak membantu teman-temannya dalam dalam bermain

10. Anak mau menerima bantuan dari Teman

11. Anak tidak bertengkar dengan teman

12. Anak sabar menunggu giliran

13. Anak tidak berebut mainan dengan Memaksa

14. Anak dapat menciptakan situasi yang kondusif saat bermain

15. Anak mau melakukan permainan sampai selesai

16. Anak mau membereskan alat permainan setelah selesai bermain

17. Anak dapat bertanggung jawab memimpin kelompok saat bermain

18. Anak memiliki inisiatif membagi temannya masuk ke dalam kelompok Bermain

19. Anak mau memberi semangat kepada Teman

20. Anak mau berbagi motivasi dengan teman dalam strategi bermain (tidak menang untuk dirinya sendiri)

21. Anak kompak bermain di dalam Kelompok

22. Anak tetap semangat meskipun kalah

$\begin{array}{llll}11 & 2 & 3 & 4 \\ 55 \% & 10 \% & 15 \% & 20 \% \\ 9 & 3 & 3 & 5 \\ 45 \% & 15 \% & 15 \% & 25 \% \\ 12 & 2 & 2 & 4 \\ 60 \% & 10 \% & 10 \% & 20 \% \\ 10 & 3 & 3 & 4 \\ 50 \% & 15 \% & 15 \% & 20 \% \\ 11 & 3 & 2 & 4 \\ 55 \% & 15 \% & 10 \% & 20 \% \\ 10 & 2 & 3 & 5 \\ 50 \% & 10 \% & 15 \% & 25 \% \\ 12 & 2 & 2 & 4 \\ 60 \% & 10 \% & 10 \% & 20 \% \\ 13 & 3 & 2 & 2 \\ 65 \% & 15 \% & 10 \% & 10 \% \\ 12 & 3 & 2 & 3 \\ 60 \% & 15 \% & 10 \% & 15 \% \\ 10 & 3 & 3 & 4 \\ 50 \% & 15 \% & 15 \% & 20 \% \\ 9 & 3 & 3 & 5 \\ 45 \% & 15 \% & 15 \% & 25 \% \\ 13 & 2 & 2 & 3 \\ 65 \% & 10 \% & 10 \% & 15 \% \\ 11 & 3 & 3 & 3 \\ 55 \% & 15 \% & 15 \% & 15 \% \\ 12 & 2 & 3 & 3 \\ 60 \% & 10 \% & 15 \% & 15 \% \\ 10 & 3 & 3 & 4 \\ 50 \% & 15 \% & 15 \% & 20 \% \\ 11 & 2 & 2 & 5 \\ 55 \% & 10 \% & 10 \% & 25 \% \\ 9 & 3 & 3 & 5 \\ 45 \% & 15 \% & 15 \% & 25 \% \\ 13 & 2 & 2 & 3 \\ 65 \% & 10 \% & 10 \% & 15 \% \\ & & & \\ 13 \% \\ 15 \%\end{array}$

Apabila ditinjau dari indikator perkembangan keterampilan sosial dan kerjasama anak, anak sudah bisa bermain sesuai peran angin puyuh, mau menerima bantuan dari teman dan mau menyelesaikan permainan, namun ada beberapa anak yang masih tidak sabar menunggu giliran, bertengkar dengan temannya, belum mau membereskan mainan, dan tidak semangat karena kalah.

Pada proses pembelajaran siklus I, ketika menggunakan media kantong plastik anak menunjukkan ketertarikan karena sebelumnya anak belum pernah bermain lomba meniup kantong plastik di sekolah, dan dengan media bulu ayam juga belum pernah di gunakan kecuali untuk kolase.

\section{Observasi}

Dalam siklus I, anak-anak mengembangkan keterampilan sosial dan kerjasama dengan bermain angin puyuh kantong plastik dan bulu ayam. Beberapa anak seperti Fairel, Fahira, Galih masih harus di bantu dan diberi motivasi lagi agar keterampilan sosial dan kerjasamanya bisa meningkat dengan baik.

\section{Refleksi siklus I}

Hasil dari pengamatan pembelajaran siklus I anak-anak mengikuti permainan dengan senang dan suasana kelas yang ramai dalam bermain angin puyuh kantong plastik dan bulu ayam. Hasil penelitian siklus I ini masih kurang maksimal dan belum sesuai target yang diharapkan sebesar $80 \%$, karena hanya menghasilkan prosentase sebesar $45 \%$. Meningkatkan keterampilan sosial dan kerjasama anak melalui bermain angin puyuh ini diharapkan akan meningkat di siklus II, sehingga dalam siklus II bermain angin puyuh menggunakan media yang berbeda. 


\section{Siklus II}

Tabel 2.

Prosentase (\%) Nilai siklus II

\begin{tabular}{|c|c|c|c|c|c|}
\hline \multirow{2}{*}{ No } & \multirow{2}{*}{ Aspek-Aspek yang diobservasi } & \multicolumn{4}{|c|}{ Jumlah Anak } \\
\hline & & BB & MB & BSH & BSB \\
\hline \multirow[t]{2}{*}{1.} & \multirow{2}{*}{ Anak menyapa teman-temannya untuk Teman } & 7 & 4 & 4 & 5 \\
\hline & & $35 \%$ & $20 \%$ & $20 \%$ & $25 \%$ \\
\hline \multirow[t]{2}{*}{2.} & \multirow{2}{*}{ Anak mengajak banyak teman untuk bermain dalam suatu kelompok } & 7 & 3 & 5 & 5 \\
\hline & & $35 \%$ & $15 \%$ & $25 \%$ & $25 \%$ \\
\hline \multirow[t]{2}{*}{3.} & \multirow{2}{*}{ Anak aktif dan mempunyai ide mengadakan permainan } & 7 & 2 & 4 & 7 \\
\hline & & $35 \%$ & $10 \%$ & $20 \%$ & $35 \%$ \\
\hline \multirow[t]{2}{*}{4.} & \multirow{2}{*}{ Anak selalu aktif bergabung dalam Bermain } & 7 & 3 & 5 & 5 \\
\hline & & $35 \%$ & $15 \%$ & $25 \%$ & $25 \%$ \\
\hline \multirow[t]{2}{*}{5.} & \multirow{2}{*}{ Anak terlibat aktif dalam permainan } & 6 & 3 & 5 & 6 \\
\hline & & $30 \%$ & $15 \%$ & $25 \%$ & $30 \%$ \\
\hline \multirow[t]{2}{*}{6.} & \multirow{2}{*}{ Anak mau bermain sesuai peran di angin puyuh (meniup) } & 6 & 4 & 5 & 5 \\
\hline & & $30 \%$ & $20 \%$ & $25 \%$ & $25 \%$ \\
\hline \multirow[t]{2}{*}{7.} & \multirow{2}{*}{ Anak tidak memaksakan kehendak kepada teman untuk bermain } & 6 & 3 & 5 & 6 \\
\hline & & $30 \%$ & $15 \%$ & $25 \%$ & $30 \%$ \\
\hline \multirow[t]{2}{*}{8.} & \multirow{2}{*}{ Anak saling berinteraksi dan berkomunikasi dengan teman } & 5 & 2 & 6 & 7 \\
\hline & & $25 \%$ & $10 \%$ & $30 \%$ & $35 \%$ \\
\hline \multirow[t]{2}{*}{9.} & \multirow{2}{*}{ Anak membantu teman dalam bermain } & 5 & 3 & 5 & 7 \\
\hline & & $25 \%$ & $15 \%$ & $25 \%$ & $35 \%$ \\
\hline \multirow[t]{2}{*}{10.} & \multirow{2}{*}{ Anak mau menerima bantuan dari Teman } & 6 & 3 & 5 & 6 \\
\hline & & $30 \%$ & $15 \%$ & $25 \%$ & $30 \%$ \\
\hline \multirow[t]{2}{*}{11.} & \multirow{2}{*}{ Anak tidak bertengkar dengan teman } & 6 & 4 & 5 & 5 \\
\hline & & $30 \%$ & $20 \%$ & $25 \%$ & $25 \%$ \\
\hline \multirow[t]{2}{*}{12.} & \multirow{2}{*}{ Anak sabar menunggu giliran } & 5 & 3 & 6 & 6 \\
\hline & & $25 \%$ & $15 \%$ & $30 \%$ & $30 \%$ \\
\hline 13. & $\Delta_{1}$ & 5 & 4 & 5 & 6 \\
\hline & 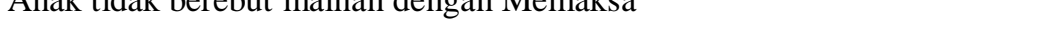 & $25 \%$ & $20 \%$ & $25 \%$ & $30 \%$ \\
\hline 14. & Anak danat mencintakan citua & 6 & 4 & 4 & 6 \\
\hline & 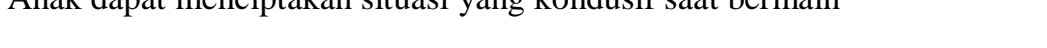 & $30 \%$ & $20 \%$ & $20 \%$ & $30 \%$ \\
\hline 15. & A pl mou mololulan normainon camnoi colocoi & 6 & 3 & 4 & 7 \\
\hline & Апак mаu mегакикап permaman sampal seresal & $30 \%$ & $15 \%$ & $20 \%$ & $35 \%$ \\
\hline 16. & A nol mou memberestan olat nermainan cetoloh colecoi hermain & 5 & 4 & 5 & 6 \\
\hline & Апак mau memoereskan aral pemraman seteran setesal bemam & $25 \%$ & $20 \%$ & $25 \%$ & $30 \%$ \\
\hline 17. & Anak danat hertanooung jawah memimnin kelomnok saat hermain & 6 & 3 & 5 & 6 \\
\hline & 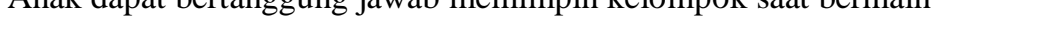 & $30 \%$ & $15 \%$ & $25 \%$ & $30 \%$ \\
\hline 18. & Anak memiliki inisiatif membagi temannya masuk ke dalam kelompok & 7 & 4 & 4 & 5 \\
\hline & bermain & $35 \%$ & $20 \%$ & $20 \%$ & $25 \%$ \\
\hline
\end{tabular}

Hasil siklus II apabila ditinjau dari indikator keberhasilan meningkatkan keterampilan sosial dan kerjasama anak dengan bermain angin puyuh sudah meningkat tetapi belum seperti yang diharapkan peneliti yaitu lebih dari $80 \%$. Pada proses pembelajaran siklus II, dengan menggunakan media lilin dan sedotan, anak menunjukkan ketertarikan pada pada permainan anginpuyuh. Media yang berbeda di setiap siklus membuat anak bersemangat untuk bermain.

\section{Observasi}

Dalam bermain angin puyuh siklus II ini, anak-anak menunjukkan peningkatan yang baik dalam meningkatkan keterampilan sosial dan kerjasama anak. Namun dalam aspek mau mengalah, tidak bertengkar dan kekompakan tim masih membutuhkan bimbingan lagi. 


\section{Refleksi Siklus II}

Berdasarkan pelaksanaan kegiatan yang dilaksanakan pada siklus II ini didapatkan bahwa keterampilan sosial dan kerjasama anak di diu puluh dua aspek penilaian sudah meningkat tetapi belum mencapai target yang telah ditentukan. Pada siklus II ini kelebihan yang di dapat yaitu Laila yang biasanya tidak mau mengalah, sudah lebih baik dengan tidak berebut mainan lagi. Namun Galih masih belum mau bersabar menunggu giliran. Penelitian ini masih termasuk kategori cukup yaitu menghasilkan prosentase sebesar $70 \%$ belum sesuai target yang diharapkan yaitu sebesar $80 \%$, maka peneliti melakukan rencana ulang pembelajaran di siklus III.

\section{Siklus III}

Tabel 3.

Prosentase (\%) Siklus III

No Aspek-Aspek yang diobservasi

1. Anak menyapa teman-temannya untuk Teman

2. Anak mengajak banyak teman untuk bermain dalam suatu kelompok

3. Anak aktif dan mempunyai ide mengadakan permainan

4. Anak selalu aktif bergabung dalam Bermain

5. Anak terlibat aktif dalam permainan

6. Anak mau bermain sesuai peran di angin puyuh (meniup)

7. Anak tidak memaksakan kehendak kepada teman untuk bermain

8. Anak saling berinteraksi dan berkomunikasi dengan teman

9. Anak membantu teman dalam bermain

10. Anak mau menerima bantuan dari Teman

11. Anak tidak bertengkar dengan teman

12. Anak sabar menunggu giliran

13. Anak tidak berebut mainan dengan Memaksa

14. Anak dapat menciptakan situasi yang kondusif saat bermain

15. Anak mau melakukan permainan sampai selesai

16. Anak mau membereskan alat permainan setelah selesai bermain

17. Anak dapat bertanggung jawab memimpin kelompok saat bermain

18. Anak memiliki inisiatif membagi temannya masuk ke dalam kelompok Bermain

19. Anak mau memberi semangat kepada Teman

\begin{tabular}{|c|c|c|c|}
\hline \multicolumn{4}{|c|}{ Jumlah Anak } \\
\hline BB & MB & BSH & BSB \\
\hline 4 & 5 & 5 & 6 \\
\hline $20 \%$ & $25 \%$ & $25 \%$ & $30 \%$ \\
\hline 3 & 6 & 6 & 5 \\
\hline $15 \%$ & $30 \%$ & $30 \%$ & $25 \%$ \\
\hline 3 & 5 & 6 & 6 \\
\hline $15 \%$ & $25 \%$ & $30 \%$ & $30 \%$ \\
\hline 3 & 4 & 5 & 8 \\
\hline $15 \%$ & $20 \%$ & $25 \%$ & $40 \%$ \\
\hline 2 & 5 & 6 & 7 \\
\hline $10 \%$ & $25 \%$ & $30 \%$ & $35 \%$ \\
\hline 2 & 6 & 6 & 6 \\
\hline $10 \%$ & $30 \%$ & $30 \%$ & $30 \%$ \\
\hline 3 & 6 & 6 & 5 \\
\hline $15 \%$ & $30 \%$ & $30 \%$ & $25 \%$ \\
\hline 1 & 5 & 6 & 8 \\
\hline $5 \%$ & $25 \%$ & $30 \%$ & $40 \%$ \\
\hline 1 & 6 & 6 & 7 \\
\hline $5 \%$ & $30 \%$ & $30 \%$ & $35 \%$ \\
\hline 2 & 5 & 6 & 6 \\
\hline $10 \%$ & $25 \%$ & $30 \%$ & $30 \%$ \\
\hline 2 & 6 & 5 & 6 \\
\hline $10 \%$ & $30 \%$ & $25 \%$ & $30 \%$ \\
\hline 1 & 6 & 6 & 7 \\
\hline $5 \%$ & $30 \%$ & $30 \%$ & $35 \%$ \\
\hline 1 & 5 & 7 & 7 \\
\hline $5 \%$ & $25 \%$ & $35 \%$ & $35 \%$ \\
\hline 2 & 5 & 5 & 8 \\
\hline $10 \%$ & $25 \%$ & $25 \%$ & $40 \%$ \\
\hline 0 & 6 & 7 & 7 \\
\hline $0 \%$ & $30 \%$ & $35 \%$ & $35 \%$ \\
\hline 2 & 6 & 6 & 6 \\
\hline $10 \%$ & $30 \%$ & $30 \%$ & $30 \%$ \\
\hline 2 & 5 & 6 & 7 \\
\hline $10 \%$ & $25 \%$ & $30 \%$ & $35 \%$ \\
\hline 1 & 5 & 6 & 8 \\
\hline $5 \%$ & $25 \%$ & $30 \%$ & $40 \%$ \\
\hline 2 & 4 & 7 & 7 \\
\hline $10 \%$ & $20 \%$ & $35 \%$ & $35 \%$ \\
\hline 2 & 5 & 6 & 7 \\
\hline
\end{tabular}




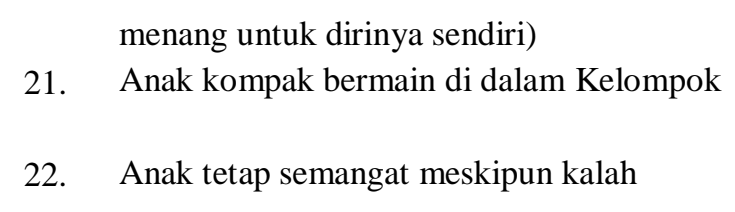

$\begin{array}{llll}10 \% & 25 \% & 30 \% & 35 \% \\ 2 & 6 & 6 & 6 \\ 10 \% & 30 \% & 30 \% & 30 \% \\ 3 & 5 & 6 & 6 \\ 15 \% & 25 \% & 30 \% & 30 \%\end{array}$

Bermain angin puyuh ditinjau dari dua puluh dua aspek penilaian, hasil yang diperoleh sudah meningkat yaitu sebesar 90\% dan telah memenuhi dari $80 \%$ yang diharapkan. Oleh karena itu penelitian dikatakan berhasil karena sudah melebihi dari target yang ditentukan oleh peneliti yaitu $10 \%$ lebih banyak. Penelitian tindakan kelas ini telah dilakukan sebanyak tiga siklus dan sudah memenuhi kriteria keberhasilan.

\section{Observasi}

Pertemuan keenam atau terakhir di sklus III ini anak-anak sudah lebih baik keterampilan sosial dan kerjasamanya, setelah melakukan senam sehat ceria di halaman sekolah anak-anak bermain angin puyuh dengan semangat. Kelompok yang biasanya tidak sabar dan tidak mau mengalah seperti kelompok Fairel, Galih dan Laila sudah baik dan bisa bekerjasama dengan teman-teman yang lainnya. Seperti pada pertemuan ini, ketika melakukan kegiatan bermain, masing-masing kelompok seperti Maulana, Fajar, Laila dan lainlain menyelesaikan permainan dengan baik. (CL 6)

\section{Pembahasan}

Tabel 4.

Hasil dari Siklus I,II,dan III

\begin{tabular}{ccc}
\hline Siklus & Persentase & Hasil Nilai \\
\hline Siklus I & $45 \%$ & Belum berhasil \\
Siklus II & $70 \%$ & Belum berhasil \\
Siklus III & $90 \%$ & Berhasil \\
\hline
\end{tabular}

Dari tabel di atas dapat ditarik kesimpulan bahwa kondisi pada siklus I dilakukan dengan hasil $45 \%$ dengan kategori kurang, setelah peneliti melanjutkan pada siklus II menghasilkan $70 \%$ termasuk dalam kategori cukup, hasil ini mengalami peningkatan sebesar 25\% dan dilakukan penelitian kembali pada siklus III yaitu $90 \%$ termasuk dalam kategori sangat baik dan mengalami peningkatan sebesar $20 \%$. Berikut ini adalah grafik peningkatan hasil penelitian :

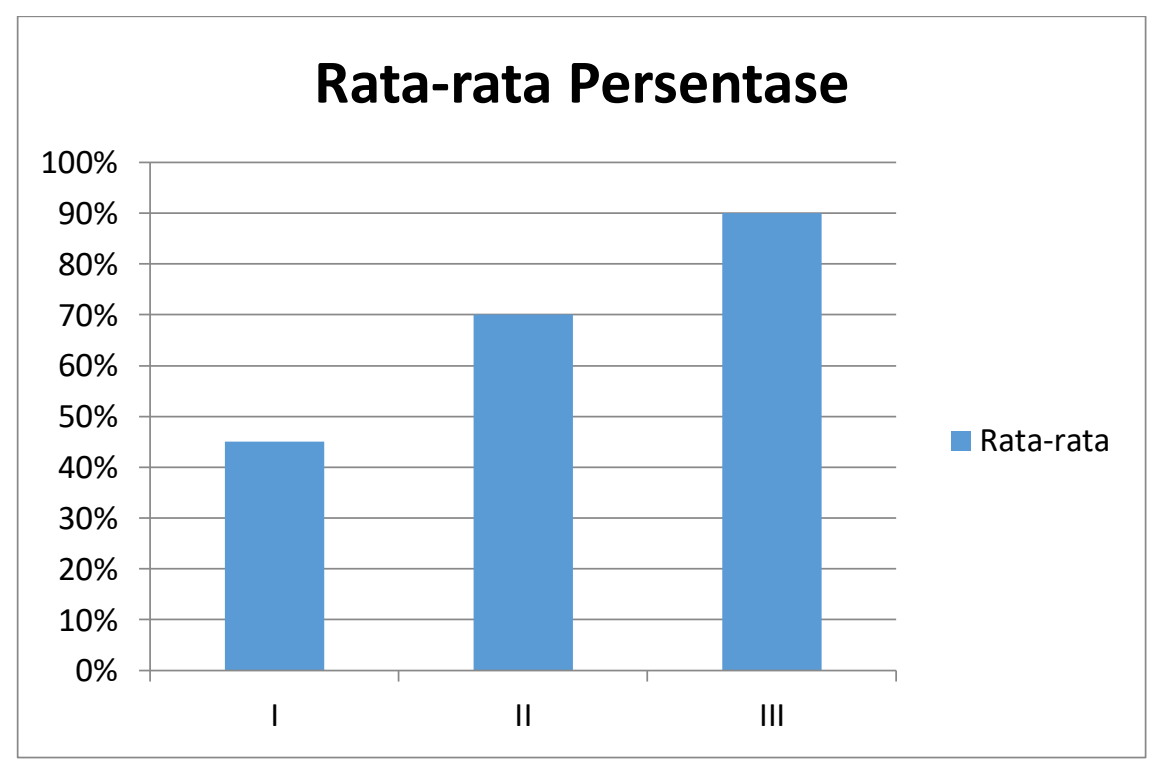

Gambar 1.

Grafik Rata-rata Persentase Hasil dari Siklus I, II, dan III

Kegiatan bermain yang bisa meningkatkan sebuah interaksi dan hubungan yang meningkatkan keterampilan sosial dan kerjasama anak di TK Al-Akbar adalah dengan bermain angin puyuh. Permainan 
angin puyuh di TK Kemala Bhayangkari ini tidak hanya akan membantu peningkatan keterampilan sosial dan kerjasama, tetapi juga mengembangkan aspek lainnya.

Aspek sosial yang terlihat dari permainan angin puyuh ini yaitu, anak melakukan kegiatan bersama dengan teman dalam kelompoknya. Mempertahankan hubungan yang sudah terbina, dan mencari pemecahan masalah yang dihadapi dengan teman dalam kelompoknya.

Permainan angin puyuh juga dapat meningkatkan aspek emosi atau kepribadian anak. dalam kegiatan bermain bersama kelompoknya, anak akan mempunyai penilaian terhadap dirinya tentang kelebihankelebihan yang dimiliki, sehingga dapat membantu pembentukan konsep diri dan harga diri yang positif, mempunyai rasa percaya diri dan harga diri karena merasa mempunyai kompetensi tertentu.

Aspek lain yang bisa diambil dari permainan angin puyuh ini yaitu untuk mengasah ketajaman penginderaan. Penginderaan meliputi penglihatan, pengecapan dan perabaan. Dengan permainan angin puyuh dapat mengasah penglihatan karena membantu anak melihat bentuk, warna, melalui media permainan angin puyuh. Untuk itu, kegiatan permainan berkelompok ini akan melatih anak dalam kerja keras, kerjasama, dan keterampilan sosial itu sendiri.

Kegiatan permainan angin puyuh ini lebih memotivasi anak untuk menumbuhkan minat anak dalam kegiatan bermain. Anak akan terbiasa dalam kerjasama dengan teman dan lebih baik dalam berinteraksi.

Hasil penelitian yang telah dilakukan mengindentifikasi bahwa kegiatan permainan angin puyuh dapat membantu anak dalam meningkatkan keterampilan sosial. Berdasarkan hasil penilaian yang telah dilakukan oleh peneliti, permainan angin puyuh melalui kerjasama dapat diimplikasikan ke pembelajaran selanjutnya dimana Guru bisa melakukan variasi permainan dengan kreativitas yang dimiliki sehingga mendukung perkembangan keterampilan sosial anak sesuai dengan harapan. Implikasi kegiatan permainan ini pada dasarnya yaitu memudahkan anak saling berhubungan dengan teman sebayanya yang merupakan teknik bermain yang menarik dan diminati anak berdasarkan gaya berpikir anak.

Hasil penelitian pada pra siklus, siklus I, II dan III dengan tingkat keberhasilan hasil kegiatan bermain yang meningkat telah membuktikan bahwa permainan ini sangat baik diterapkan pada anak terutama anak usia dini yang dimana masih dalam proses penyerapan berbagai informasi. Hal ini terlihat pada perilaku anak di sekolah yang kurang dalam berbagi dengan teman, tidak mau mengalah dan kerjasama anak dengan kelompok atau teman sebaya masuk dalam kategori kurang, dalam hal ini stimulasi tidak hanya pada kegiatan bermain tetapi dapat dilakukan saat guru mendekati dan berinteraksi dengan murid.

\section{SIMPULAN}

Berdasarkan hasil penelitian dan pembahasan maka dapat disimpulkan bahwa kegiatan permainan angin puyuh dengan kerjasama dapat meningkatkan keterampilan sosial anak sesuai dengan analisis data, terlihat dari hasil pra siklus, siklus I, siklus II dan siklus III. Aktivitas permainan angin puyuh dengan kerjasama meningkat dari pra siklus, siklus I sampai siklus III.

Dari 20 anak, dapat dilihat jumlah anak yang memiliki keterampilan sosial dan kerjasama yang baik. Pada siklus 1 atau sebesar $45 \%$ yang termasuk pada kategori kurang dan pada siklus II sebesar $70 \%$ yang berarti termasuk kategori cukup, dan siklus III sebesar 90\%. Aktivitas permainan angin puyuh dengan kerjasama meningkat dari siklus I sampai siklus III.

Keterampilan sosial dan kerjasama setelah mengikuti kegiatan bermain angin puyuh mengalami perubahan yang baik. Perubahan tersebut terlihat sekali ketika anak berinteraksi dengan teman dalam permainan kelompok. Anak dapat aktif dalam proses kegiatan pembelajaran, serta anak menjadi tertarik dan antusias mengikuti kegiatan permainan.

\section{DAFTAR PUSTAKA}

Aqip, Zainal dkk. 2008. Penelitian Tindakan Kelas Untuk Guru SD, SLB,dan TK. Bandung : CV Yrama Widya.

Arikunto, Suharsini. 2010. Prosedur Penelitian.Jakarta : PT Rineka Cipta.

Hariwijaya, M \& Bertiani Eka Sukaca. 2009. PAUD Melejitkan PotensiAnak dengan Pendidikan Sejak Dini. Yogyakarta: MahadikaPublishing.

Montolalu, B.E.F. 2009. Bermain dan Permainan Anak. Jakarta: Departemen Pendidikan Nasional. 
Saputra, Yudha M \& Rudyanto. Pembelajaran kooperatif UntukMeningkatkan Keterampilan Anak TK. Jakarta: DepartemenPendidikan Nasional.

Seefeldt, Carol \& Barbara.2008. Pendidikan Anak Usia Dini. Jakarta: PT Macanan Jaya Cemerlang. 